\title{
Pendaftaran Hak Tanggungan
}

\author{
Oleh : Marla S.W. Sumardjono
}

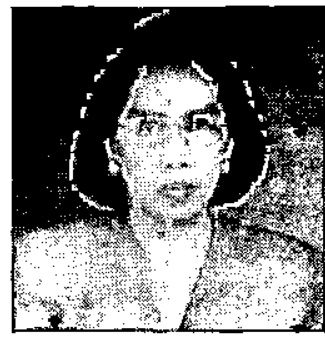

Dr. MariaSWSumardjono,SH.MCL.MPA adalah Lektor Kepala dan Dekan pada Fakultas Hukum Universitas Gadjah Mada di Yogyakarta. Lulus sebagaiSarjana Hukum dari Fak. Hukum Universitas Diponegoro Semarang (tahun 1966). Master of Comparative Law diperoleh pada 1978 dari Southern Methodist Univer sity (USA); Master of Public Administration diperoleh dari Southem California University (USA) pada tahun 1984; sedangkan derajad Doktor (Ph.D) diperoleh dari Southern California University (USA) pada tahun 1988. Disamping menulis beberapa buku seperti "Puspita Serangkum", Tinjauan Kasus Beberapa Masalah Tanah" serta "Hukum dan Masalah Perumahan di Negara Berkembang" Dr. Maria SW Sumardjono banyak menulis antikel di berbagai majalah hukum maupun media massa umum serta produktif menulis makalah untuk seminar-seminar nasional maupun internasional sesuai dengan keahliannya yang berkonsentrasi pada masalah-masalah hukum agraria.

\section{Pengantar}

Artikel ini difokuskanpada salah satu aspek dalam mata rantai pengikatan jaminan, khususnya dengan objek tanah, dengan adanya kemungkinan untuk menjadikan sebagai agunan tanah yang kepemilikannya didasarkan pada hukum adat yang bukti kepemilikannya berupa girik, petúk, dan lain-lain, sebagaimana tercantum Penjelasan Pasal 8 UndangUndang No. 7 Tahun $1992^{\circ}$ tentang Perbankan.

Masalah ini dipilih berdasarkan tiga pertimbangan: Pertama, mengikuti seccara harfiah bunyi Penjelasan Pasal 8 tersebut dapat menimbulkan berbagai kesulitan. Kedua, dengan adanya Konsep Rancangan Undang-Undang tentang Hak Tanggungan Atas Tanah dan Benda-benda yang berkaitan dengan tanah (selanjutnya disingkat
KRUUHT), itikad baik yang diujudkan dalam Penjelasan Pasal 8 tersebut telah ditampung untuk diberikan upaya pengamanainnya. Ketiga, walaupun tanah sudah didaftarkan seringmuncul isu tentang ketidakberesansertipikat tanah yang secara tidaklangsung juga akanmembawadampak yang merugikan, terutama pemegang Hak Tanggungan.

Pemegang Hak Tanggungan, Fungsi serta Implikasi Yuridisnya

Latar belakang diberikannya kemungkinan menjadikan sebagai agunan tanah yang kepemilikannya didasarkan pada hukum adat dengan bukti kepemilikan berupagirikdansebagainya,dapat dipahami dari segi pandang realistis-pragmatis.

Kenyataan menunjukkan bahwa dalam kurun waktu tiga puluh satu tahun 
setelah berlakunya Peraturan Pemerintah No. 10 Tahun 1961 tentang Pendaftaran Tanah, jumlah bidang tanah yang terdaftar di Indonesia kurang lebih 12 juta bidang dari 55 juta bidang, atau sekitar 21,8 persen (Supranowo, 1992). Dapat dipahami bahwa sebagian terbesar dari sekitar 78 persen bidang tanah yang belum terdaftar tersebut, terdiri dari tanah-tanah yang berdasarkan hukum adat:

Hal ini dapat terjadi karena beberapa kemungkinan:Pertama, dari sisi pemegang Hak Milik yang berasal dari konversi hak milik adat, bila terhadap tanahnya tidak ada suatu peristiwa hukum yang wajib didaftar karena hak beralih, hapus, dan dibebani dengan hak-hak lain maka kewajiban untuk mendaftarkan tanah tidak ada. Yang terkena kewajiban untuk mendaftarkan Hak Milik adalah pemegang Hak Milik yang berasal dari pemberian Pemerintah sesudah berlakunya Peraturan Pemerintah No. 10 Tahun 1961. Kewajiban ini harus ditepati, karena pendaftaran merupakan syarat konstitutif untuk lahirnya Hak Milik tersebut.

Kedua, adanya hambatan berupa keterbatasan dana Pemerintah serta personalia pelaksana dibandingkan dengan luasnya wilayah yang harus dilakukan pendaftarannya.

Ketiga, adanya kecenderungan berupa keengganan mendaftarkan tanahnya apabila tidak ada keperluan yang mendesak (misalnya jual-beli, hibah, memperoleh kredit dengan tanah sebagai jaminan, dan lain-lain) yang dilandasi oleh berbagai hal, seperti jangka waktu pemrosesan, masih belum meratanya pengetahuan masyarakat tentang arti pentingnya mendaftarkan tanahnya (Sumardjono, 1992).

Karena disadari bahwa sebagian terbesar masyarakat, terutama yang bertempat tinggal di luar daerah perkotaan, tanah-tanahnya belum terdaftar, sedangkan keperluan untuk memperolehkreditdengan tanah sebagai agunan tidak dapat dikesampingkan begitu saja, maka PenjelasanPasal 8 tersebut dapat dipandang sebagai terobosan untuk menampung keadaan nyata tersebut.

Namun demikian, kesulitan yang dihadapi adalah bahwa secara yuridis girik dan sebagainya itu bukanlah alat bukti hak sebagaimana dimaksud oleh Peraturan Pemerintah No. 10 Tahun 1961 dengan akibat tidak dapat segera dilakukan pedaftaran Hak Tanggungannya.

Dalam KRUUHT keadaan ini ditampung dan diberikan jalan keluarnya. Disebutkan dalam KRUUHT tersebut bahwa apabila objek Hak Tanggungan berupa Hak Milik atas tanah yang berasal dari konversi hak yang lama yang telah memenuhi syarat untuk didaftarkan (dengan perkataan lain haknya telah ada), tetapi pendaftarannya belum dilakukan, maka Pemberian Hak Tanggungan dilakukan bersamaan dengan permohonan pendaftaran hak atas tanah yang bersangkutan. Ditampungnya masalah ini di dalam KRUUHT mengandung arti bahwa ketiadaan alat bukti hak tidak menutup kemungkinan untuk memperoleh kredit di samping bahwa ketentuan ini juga dimaksudkan untuk mendorong pensertipikatan hak atas tanah pada umumnya.

Berdasarkan kenyataan bahwa terdapat dua macam hak atas tanah adat, yakni tanah-tanah hak yang mempunyai tanda bukti dan yang tidak mempunyai tanda bukti, maka tata cara pendaftarannya diatur dalam Peraturan Menteri Pertanian dan Agraria No. 2 Tahun 1962 tentang Penegasan Konversi dan Pendaftaran Bekas 
Hak-hak Indonesia Atas Tanah, ditambah dengan Surat Keputusan Menteri Dalam Negeri No. SK.26/DDA/1970 yang mengatur tentang hal yang sama.

Bagi tanah-tanah yang sudah ada bukti haknya yang memenuhi syarat, penegasan konversi dan pendaftarannya dilakukan sekaligus. Surat tanda bukti termaksud adalah yang dibuat berdasarkan Ordonansi Balik Nama (S 1834 No. 27), Peraturan Menteri Daerah Istimewa Yogyakarta, Karesidenan Surakarta dan Sumatera Timur (Pasal 2 Peraturan Menteri Pertanian dan Agraria No. 2 Tahun 1962), pajak hasil bumi/verponding Indonesia atau surat pemberian hak oleh instansi yang berwenang (Pasal 3 Peraturan Menteri Pertanian dan Agraria No. 2 Tahun 1962); dan di daerah yang sampai dengan tanggal 24 September 1960 belum dipungut pajak hasil bumi/verponding Indonesia, bukti hak berupa surat asli jual beli, hibah atau tukarmenukar yang dibuat di hadapan dan disaksikan oleh Kepala Desa/Adat yang bersangkütan sebelum diselenggarakannya Peraturan Pemerintah No. 10 Tahun 1961 (Surat Keputusan Menteri Dalam Negeri No. 26/DDA/70).

Bagi tanah-tahah yang tidak ada atau tidak ada lagi tanda bukti hanya diperlukan Surat Keputusán Pengakuan Hak oleh instansi yang berwenang agar dapat dilakukan pendaftarannya.

Dengan pendaftaran tersebut akan diperoleh sertipikat secara teknis yuridis terdiri dari salinan buku tanah dan surat ukur yang dijahit menjadi satu dalam satu dokumen. Fungsi sertipikat adalah sebagai alat bukti hak yang kuat.

Dengan adanya Surat Keputusan Badan Pertanahan Nasional No.2/1992 tentang Biaya Pendaftaran Tanah, maka biaya pembuatan sertipikat untuk hak atas tanah bekas hak adat yang belum diuraikan dalam suatu surat hak atas tanah bila pemegang haknya adalah perorangan atau badan keagamaan, badan sosial, dan badan lain yang ditunjuk oleh Kepala Badan Pertanahan Nasional atas dasar persetujuan tertulis Menteri yang bersangkutan, untuk masing-masing dikenakan biaya sebesar Rp. 10.000,00 jika tanah yang bersangkutan terletak di daerah perkotaan dan Rp. $1.000,00$ jika tanah yang bersangkutan terletak di luar daerah perkotaan (Pasal 2 Surat Keputusan Kepala Badan Pertanahan Nasional No.2Tahun 1992). Bila pemohon adalah badan hukum, untuk tanah yang terletak di daerah perkotaan maupun luar perkotaan dikenakan biaya sebesar Rp. $100.000,00$.

Dalam KRUUHT disebutkan bahwa Hak Tanggungan wajib didaftarkan pada Kantor Pertanahan. Alasannya ialah karena untuk memenuhi salah satu asas Hak Tanggungan, yakni asas publisitas. Pendaftaran Hak Tanggungan tersebut merupakan syarat mutlak untuk lahimya Hak Tanggungan tersebut dan mengikatnya Hak Tanggungan terhadap pihak ketiga, atau dengan perkataan lain kreditur memperoleh kedudukan preferensi.

Karena proses pendaftaran Hak Tanggunganmemerlukan peranan aktif dari PPAT, maka diletakkan kewajiban bagi PPAT untuk mengirimkan Akta Pemberian Hak Tanggungan yang bersangkutan dan warkah-warkah lain yang diperlukan, selambat-lambatnya 7 (tujuh) hari kerja setelah penandatanganan Akta Pemberian Hak Tanggungan tersebut. Kelalaian untuk menepati kewajiban tersebut akan dikenakan sanksi yang akan ditetapkan dalam peraturan perundang-undangan yang mengatur jabatan PPAT.

Hak Tanggungan lahir pada hari 
tanggal buktu tanah Hak Tanggungan, yakni pada hari ke tujuh setelah penerimaan secara lengkap surat-surat yang diperlukan bagi pendaftarannya. Pembatasan waktu pembuatan buku tanah Hak Tanggungan dimaksudkan agar penyelesaian pendaftaran Fak Tanggungan yang merupakan kewajiban itu tidak berlarutlarut.

Dengan telah didaftarkannya Hak Tanggungan tersebut, sebagai tanda bukti adanya Hak Tanggungan, oleh Kantor Pertanahan diterbitkan sertifikat Hak Tanggungan yang terdiri dari salinan buku Tanah Hak Tanggungan dan salinạn Akta Pemberian Hak Tanggungan yang dijahit menjadi satu dalam sampul dokumen. Sertifikat Hak Tanggungan yang bersangkutan diserahkan kepada pemegang Hak Tanggungan. Beaya untuk pembuatan settipikat Hak Tanggungan bila pemohon perorangan atau badan hukum keagamaan dan sosial adalah Rp. 10.000,00 (jika tanah terletak di luar daerah perkotaan) dan $\mathrm{Rp}$. $1.000,00$ (bila tanah terletak di luar daerah perkotaan). Bila pemohon badan hukum, maka dikenakan beaya Rp. 100:000,00, baik terhadap tanah yang terletak di daerah perkotaan ataupun daerah luar perkotaan.

Pada masa yang lalu terdapat banyak Hak Tanggungan yang tidak didaftarkan, tetapi hanya sampai pada tahap Surat Kuasa Memasang Hipotik (SKMH) atau Surat Kuasa Memasang Credit Verband (SKCV) yang salah satu alasannya adalah karena belum semua hak atas tanah mempunyai sertifikat. Dalam KRUUHT, disebutkan juga adanya kemungkinari untuk menggunakan Surat Kuasa Membebankan Hak Tanggungan yang wajibdibuat dengan akta otentik dan memenuhi syarat tertentu, yakni: (1) tidak memuat kuasa untuk melakukan perbuatan hukum lain, selain membebankan Hak Tanggungan (2) tidak memuat kuasa substitusi; dan (3) mencantumkan secara jelas jumlah kredit d́an nama serta identitas kreditur. Kemungkinan ini diberikan hanya dalam hal pemberi Hak Tanggungan benar-benar tidak hadir di hadapan PPAT. Tidak dipenuhinya syarat-syarat termaksud, akan mengakibatkan surat kuasa yang bersangkutan batal demi hukum.

Berbeda, dengan waktu yang lalu', dari KRUUHT Surat Kuasa Membebankan Hak tanggungan jangka waktunya dibatasi, dalam arti harus diikuti dengan pembuatan Akta Pemberian Hak Tanggungan, dan kemudian diikuti dengan pendaftarannya. Terhadap hak ataś tanah wajib dilakukan selambat-lambatnya 3 (tiga) bulan sesudah sesudah diberikan dan terhadap hak atas tanah yang sudah terdaftar wajib diikuti dengan pembuatan Akta Pemberian HakTanggungan selambat-lambatnya 1 (satu) bulan sesudah diberikan. Bila jangka waktu tersebut lewat dan persyaratan tidak ditepati, maka surat kuasa tersebut batal demi hukum.

Melihat pada pengalaman di masa lalu di mana timbul isyu tentang ketidakberesan setifikat tanah, maka perlu dilakukan tindakan berupa penghati-hatian untuk mengadakan penelitian seperlunya terhadapa alat bukti hak tersebut.

Pada umumnya isyu tentang sertifikat yang tidak beres tersebut berkaitan dengan adanya sertifikat ganda, sertifikat palsu, dan sertipikat aspal (asli tetapi palsu) (Soni Harsono, 1990). Sertifikat ganda adalaḥ sertifikat yang diterbitkanilebih dari satu oleh Kantor Pertanahan, sehingga berakibat dua atau lebih tanah hak saling bertindihan seluruhnya atau sebagian. Kasus ini dapat terjadi karena dua kemungkinan, yakni: (1) sebagai akibat 
kesalahan penunjukan batas tanah oleh pemohon, dan (2) dapat pula terjadi atas tanah warisan yang disebabkan oleh sengketa harta warisan dimana pewaris tanpa sepengetahuan ahli waris telah menjual tanahnya dan diterbitkan sertifikatnya atas nama pembeli; sedangkan pihak ahli warismendaftarkan bidang tanah yang sama.

Sertifikat asii tetapi palsu adalahsertipikat yang diterbitkan oleh Kantor Pertanahan, tetapi surat-surat bukti sebagai alas/dasar penerbitan sertifikat tidak benar atau dipalsukan.

Bagi kreditur tidak ada pilihan lain kecuali mengadakan penelitian tentang kebenaran formal sertifikat tanah serta meneliti apakah tanah hak yang dimaksud benar-benar ada dalam kenyataannya.

\section{Penutup}

Dari segi yuridis salah satu upaya pengamanan dalam penyaluran dan pengembalian kredit adalah melalui pengikatanjaminan.Lembagajaminan yang dapat dibebankan terhadap hak atas tanah yang disebut dengan' Hak Tanggungan mempunyai kedudukan yang kuat mempunyai ciri-ciri: (1) memberikan hak preferensi kepada pemegang; (2) selalu mengikuti objek di tangan siapa pun objek itu berada; (3) memenuhi asas spesialitas dan publisitas sehingga mengikat pihak yang berkepentingan; dan (4) mudah dan pasti pelaksanaan eksekusinya.

Agar supaya kedudukan yang kuat dari Hak. Tanggungan itu tercapai dan kepentingan kreditur maupun debitur terjamin, maka keharusan untuk menepati secara konsekuen semua tata cara dalam pengikatan jaminan merupakan hal yang mutlak harus dilakukan.

\section{Referensi}

Soni harsono, 1990. Masalah Pertanahan, makalah disampaikan pada Pra Simposium Bidang Pertanahan Koordinator Bidang Hukum dan Umum DPP Golkar, Jakarta, 25 Mei 1990.

Sumardjono, Maria, 1992. Pendafiaran Tanah, Antara.Harapan dan Kenyataan, makalah disampaikan pada Seminar Nasional "Kegunaan Sertifikat dan Permasalahnya", kerja sama Fakultas Hukum UGM Badan Pertanahan Nasional, Yogyakarta, 9 Juli 1992.

Supranowo, 1992. Perkembangan Kebijaksanaandi Bidang Pendaftaran Tanah dan Penyediaan Informasi Pertanahan Secara Terpadu, makalah disampaikan pada. Diskusi Panel Fakultas Hukum Universitas Trisaksi dalam rangka memperingatiHUTUUPA keXXXII, Jakarta, 31 Oktober 1992. 